\title{
台風期における人エリーフ背後の 海浜変形の素過程 \\ SEASONAL BEACH PROCESS AROUND ARTIFICIAL REEF \\ AT IDA BEACH IN SHICHIRI-MIHAMA COAST
}

\author{
和田 清1・水谷法美2 \\ Kiyoshi WADA and Norimi MIZUTANI \\ 1正会員 工博 岐阜工業高等専門学校助教授 環境都市工学科（テ501-0495 岐阜県本巣郡真正町上真桑） \\ 2正会員 工博 名古屋大学大学院助教授 工学研究科土木工学専攻（テ464-8603 名古屋市千種区不老町）
}

\begin{abstract}
This paper is intended to estimate seasonal beach process and wave deformations around artificial reefs at the Ida beach in the Shichiri-Mihama coast in Mie Prefecture. It is clear that almost regions occurred beach erosion, especially Udono port region located on the left bank of the Kumano river, as the coastal line faced to sea, the beach protection works were struck by strong storms. In order to prevent erosion and make a stable beach, the application of beach nourishment behind artificial reefs was examined by Mie Prefectural Government. A series of surveys and studies on sand drift and wave conditions were conducted in order to examine the sand drift process, the possibility of applying beach nourishment and its executive way at the Ida beach. There are the formation of berm and tombolo topography behind artificial reefs. Results were estimated on the sediment volume and the predominant direction of sand transport and the correlation between longshore sand transport volume and wave condition. On the basis of these results, the amount of sediment transport in longshore direction were estimated thirty thousands cubic meters a period of typhoon season at the boundary.
\end{abstract}

Key Words : beach process, sediment transport, erosion control, artificial reef, wave deformation

\section{1.はじめに}

全国の多くの海岸では，海岸侵食が問題化してお り，近年特に深刻化している場合が少なくない1)2). しかしながら，河川からの供給土砂の量亡質，来襲 波浪や流れ場の特性, 土砂の移動機構についての観 測や調査がまだ不十分であり，海岸侵食の機構と原 因を特定しにくく，総合的な海岸保全対策を実施す ることが困難な現状である。

三重県南端に位置する七里御浜海岸は，熊野灘に 面した延長約 $20 \mathrm{~km}$ の砂碩浜であり，ここでも海岸 侵食が深刻化している3 ${ }^{4)}$. 特に，熊野川河口の鵜 殿港北側に位置する井田地区海岸は，平成9年に来 襲した複数の大型台風により，海岸堤防が $720 \mathrm{~m} に$ わたって破堤するなど甚大な被害を受けた5) 6). そ の後, 災害再発防止のために海岸堤防の嵩上げなど の改良工事を行なうとともに，海岸堤防への来襲波 浪の低減と人エリーフ背後への堆砂の促進を図るた めに, 長さ $200 \mathrm{~m}$ のエリーフの設置が 6 基建設され た。また，継続的な波浪観測を行なうために，超音 波式波高計の設置に加えて，全国でも珍しい短波海 洋レーダー（HFレーダー）の観測局が運用されて
いる．陸上から観測が可能なリモートセンシング方 式によって, 広域でかつ準リアルタイムな波浪情報 が得られる。ささらに，三重県によって「七里御浜海 岸海岸侵食対策検討会」が組織され，台風期の海浜 地形変動や沿岸漂砂量を明らかにするために，人工 リーフ背後の養浜工事とモニタリング調査（汀線・ 深浅測量，底質調査）が実施されている.

本研究は, 井田海岸を対象にして, 台風期におけ る人エリーフ群周辺の海浜変形過程を明らかにする ために，既存の資料解析に加えて，DGPSによる汀 線測量や地形測量を新たに年数回行い, 波浪特性と 海浜変動特性について考察を加えたものである.

\section{2. 資料解析および現地調査の概要}

\section{（1）三重県による養浜エおよびモニタリング調査}

井田海岸における人エリーフ配置の概略を図－1 に示す. なお，図中の数值は後述する深浅測量断面 である。図中左端の岩礁が梶ヶ鼻であり，高潮対策 事業で人工リーフ1基が建設された。 その後，平成6 年災害復旧事業により3基が増設され，もう一方の 岩礁までの区間が完成した。平成9年海岸災害復旧 


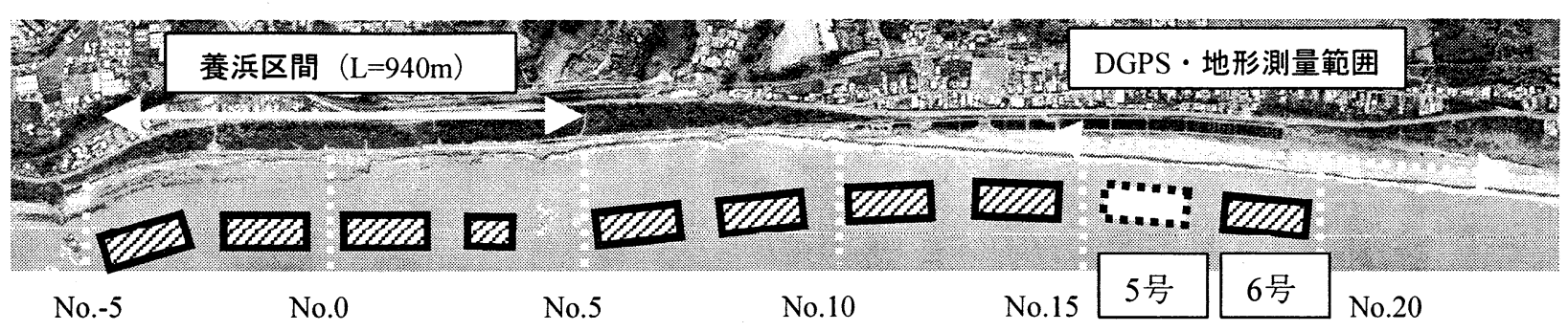

図-1 調査対象海岸（井田海岸: 三重県七里御浜）

助成事業で4基が建設されたが，1基飛ばして6番目 の人エリーフ（全長 $200 \mathrm{~m}$,幅 $80 \mathrm{~m}$ ）が先に設置され た。昨年12月にようやく5番目（図中破線）がほぼ 完成した。 したがって，昨年の調查中は，この人工 リーフは完成断面ではなく，波浪が直接消波ブロッ クに作用して, ブロック前面の前浜が消失した状態 となっている，また，昨年の台風によって，消波ブ ロックは沈下し, 背後の保安林の護岸法面が崩壊す る状態に至っている. なお, 井田海岸の全体計画で は，10号までの設置が予定されている.

養浜工の概要は以下のようである. 図中の養浜区 間 $940 \mathrm{~m}$ （深浅断面：No. $-5 \sim$ No.5）において, 平 成 13 年 1 月 5月の期間, 体積 $36,460 \mathrm{~m}^{3}$ の養浜材

（中央粒径 : $\mathrm{d}_{50}=28 \mathrm{~mm}$ ) が投入された. 投入断面 形状は, 護岸天端から沖側に幅 $13 \mathrm{~m}$, 養浜断面の天

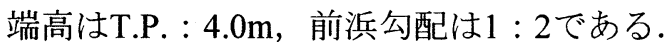

養浜のモニタリング調査は, 養浜直後の平成 13 年 5 月 28 日〜 6 月 12 日，同年 10 月 10 日〜 11月 17 日の 2 回， 図中のNo. $-5 \sim$ No. 20 までの区間約 $2.5 \mathrm{~km}$ を $100 \mathrm{~m}$ 間 隔に沖合 $2500 \mathrm{~m}$ の範囲で, 媣浅測量が行なわれた. 後述するように，その期間に台風が2回来襲してお り，簡易測量が同年8月24日〜25日，同年9月18日に 実施されている.

\section{（2）DGPSによる汀線測量および後浜の地形測量}

養浜工のモニタリング調查と並行して, 人エリー フ6号を中心とする汀線と後浜地形の測量を実施し した．人エリーフ5号は設置されていないので，6号 の背後はトンボロ地形が形成されている.

汀線形状の短期的変動を調査するために, DGPS による測量を, 平成12年9月〜平成13年11月の期間, 計9回実施した。DGPSはGPSに地上波（中波ビーコ ンとFM多重波）による補正を加えて，位置精度を 向上させたものである.なお，この結果は文献7)8)9) ${ }^{10)}$ に記載されているので, 本論文では省略する.

さらに, 平均海面より陸側の 3 次元的な海浜地形 特性を把握するために, トータルステーションによ る地形測量を行なった. 後浜の地形測量については, 台風 11 号来襲後の平成 13 年 8 月 $29 \sim 30$ 日, 台風 15 号 接近後の9月28〜29日, 11月13〜14日の3回行なった. なお, 平成12年9月〜平成13年 2 月までの期間, 計3 回の地形測量を実施している.

\section{(3) 来襲波浪と流れ場の観測網}

対象海岸では, 鵜殿港の沖合 $2.1 \mathrm{~km}$, 水深 $25 \mathrm{~m}$ の 地点に超音波式波高計と流向流速計が設置され, 平 成11年度〜平成13年6月まで観測された。さらに,
わが国初の本格的なHFレーダー（汀線方向約 $12 \mathrm{~km}$, ビーム間隔7.5 ）を用いた波浪観測システムも平 成12年度から実施されており, 点情報だけでなく面 的な波浪場の情報が得られている。台風期の波浪 データはHFレーダーのみなので, その時系列デー 夕を中心に, 波高 - 周期 - 波向きの波浪の基本特性 に着目して整理を行った。

\section{3. 来襲波浪の基本特性}

\section{（1）来襲した台風の特性}

平成13年8月には台風 11 号が,また9月には台風 15 号が相次いで上陸している. 図一2 2 台風の進路と 規模を示したものである. 台風11号は，太平洋沖で 発生し勢力はとても強く広範囲にわたり強風域・暴 風域を広げており, 強風域は日本列島を覆ってしま うほどであった。台風11号は日本の紀伊半島に進行 していたが，進路を変え日本列島を継断するように 東日本の海岸を北上した。この台風の気圧は最も低 い時が $960 \mathrm{hPa}$ であり, 日本の紀伊半島に上陸する頃 には970hPaである.この台風11号が対象海岸に最も 接近したのが 8 月 22 日の午前6時である. 最大風速は $35 \mathrm{~m} / \mathrm{s}$ で対象海岸に近づく頃は25〜30m/sである.

台風 15 号も 11 号と同様太平洋沖で発生し勢力が強 く, 強風域・暴風域は台風11号に比べ範囲は小さい が気圧は低く風速が大きい. 台風15号は日本の紀伊 半島に向けて進行していたが，11号同様進路を変え 日本列島を緹断するように東日本の海岸を北上した. この台風の気圧は最も低い時が955hPaであり, 伊勢 湾に近づく頃には965hPaとなり，その後日本列島を 縌断するにつれ徐々に勢力は弱まっていった。この 台風 15 号が最も接近したのは9月 10 日の午後 9 時から 9月 11 日の午前3時である. 対象海岸が強風域に入っ ている期間は台風 11 号より長く海岸が大きく影響を 受けていたのではないかと考えられる. なお，最大

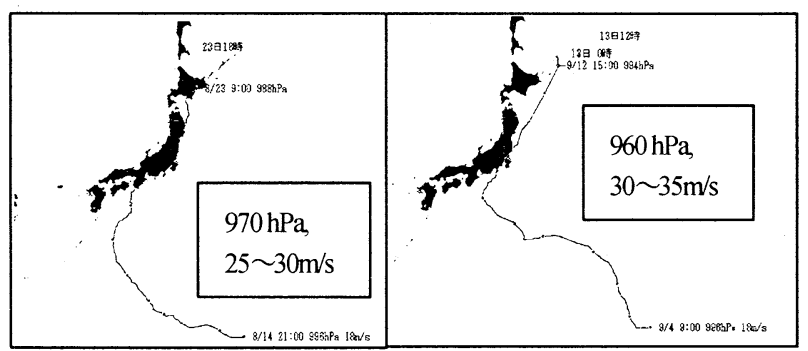

(a) 台風11号（8月）

(b) 台風 15 号 (9月)

図-2 台風の進路と規模 (接近時の中心気圧と風速) 


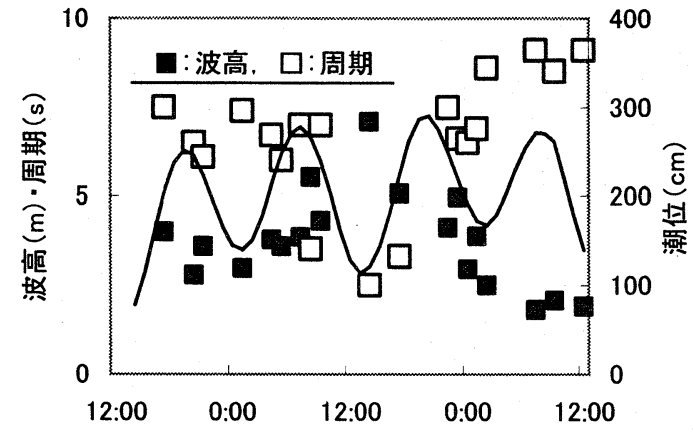

(a) 台風11号（8月20～22日）

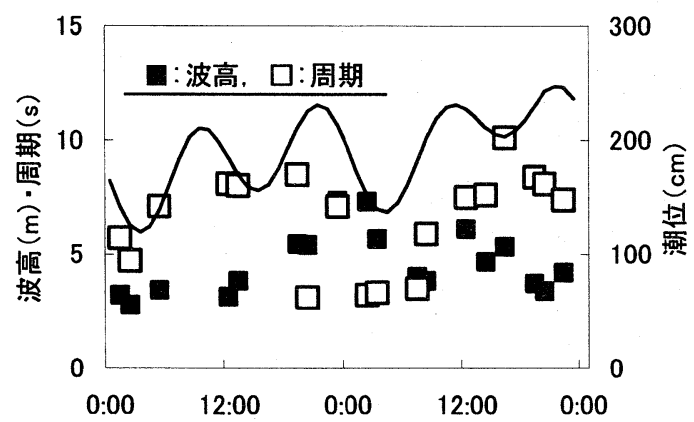

(b) 台風15号（9月9～10日）

図一 3 波浪特性と潮位変動

風速は $40 \mathrm{~m} / \mathrm{s}$ で対象海岸に近づく頃は $30 \sim 35 \mathrm{~m} / \mathrm{s}$ で あった．台風11号と異なり対象海岸を通過する直前 で進路を変えている，台風の勢力は紀伊半島沖では $960 \mathrm{hPa}$ ，風速 $35 \mathrm{~m} / \mathrm{s}$ ，遠州灘で $970 \mathrm{hPa}$ ，風速 $35 \mathrm{~m} / \mathrm{s}$ で あった．上陸している期間は少しの間であったこと もあり，日本に接近しても勢力はあまり衰えること なく台風11号よりも強力な台風であった.

\section{（2）波浪特性と潮位変動}

図ー3は，HFレーダーによって得られた台風接 近前後の波浪特性（波高および周期）と潮位変動の 時系列を示したものである. 同図から，台風11号で は，8月21日 14:00に波高7.08m の高波が干潮時に来 襲したこと，台風15号によって9月9日23:00〜10日 2:00の深夜の下げ潮時に，波高7.32〜 7.36m の暴浪 が襲ったことがわかる．また，周期については最大 波高時で $2.5 \sim 3.2 \mathrm{~s}$ と極端に短くなっている. 高波浪 時を除くと周期 5 〜 10 s程度なので通常の風波の領域 に近い，図－4は，7月1日〜11月13日の期間におけ る波高と周期の相関を示したものである. 図中の破 線で囲った領域は, 波高 $4 \mathrm{~m}$ 以上, 周期約 $3 \mathrm{~s}$ の波浪 である．同図からわかるように，波高が $4 \mathrm{~m}$ 以上の 高波浪時には，周期は約 3 秒と6〜10sのグループに 大別されてしまうので, 台風接近時の暴浪の周期に ついては, 短波海洋レーダーによる分離方法など, 検討すべき課題が残されているといえる.

図－5 は，台風15号来襲前後（9月7〜12日）にお ける平均波向と波高の推移を示したものである. 対 象海岸の汀線の方位角は約 $14^{\circ}$ であり, その法線の 角度 104 を境にして, 沿岸漂砂の卓越方向が異な ることになる. 同図から, 台風が接近する以前には $\mathrm{S} \sim \mathrm{SEE}$ 方向からの入射が多く(北向きの沿岸漂砂),

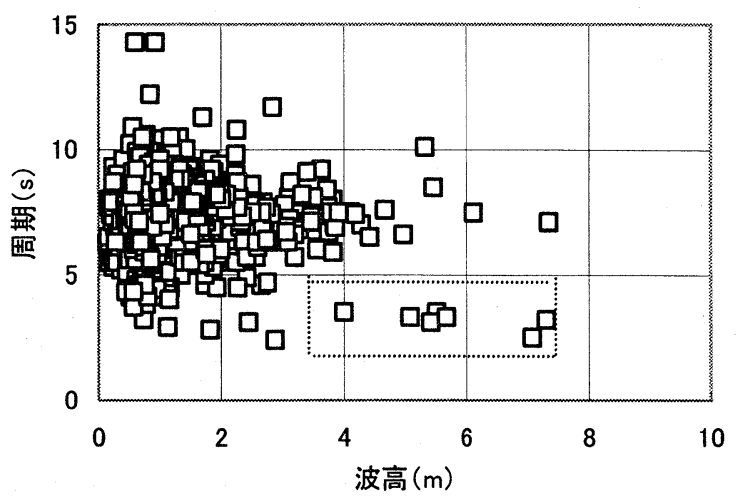

図-4 波高と周期の相関（7/1〜11/13）

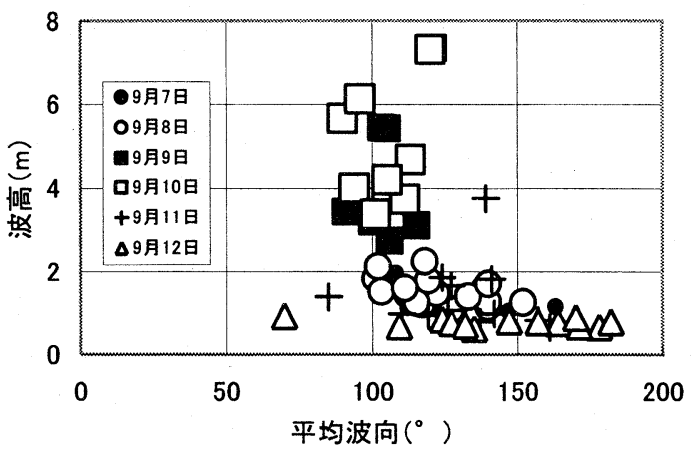

図-5 台風15号接近時の波高と波向きの推移

接近時になると汀線に直角な入射成分（E〜SEE成 分）が多くなることがうかがえる. その後, 再びS 〜SEE方向へ戻るなど，波向きが台風の接近ととも に短期的に大きく変動していることがわかる.

\section{4. 人エリーフ周辺の海浜地形変動}

\section{（1）養浜エと人エリーフ群の海浜断面}

三重県によって養浜のモニタリング調査 ${ }^{11)}$ が行 なわれているので, その実測データを用いて台風期 前後における海浜断面の違いを見ていこう.

図一 6 は，養浜区間（No.-5～5）の代表例とし て, No.一3における台風期前後の海浜断面の比較を したものである. 養浜材の投入は平成13年1月下旬 ～5月下旬にかけて行なわれ，養浜後の第1回目の深 浅測量は5月下旬から6月中旬にかけて実施された。 したがって, 養浜施工から海浜断面の測定までに時 間差が生じており，その間に来襲した波浪により養

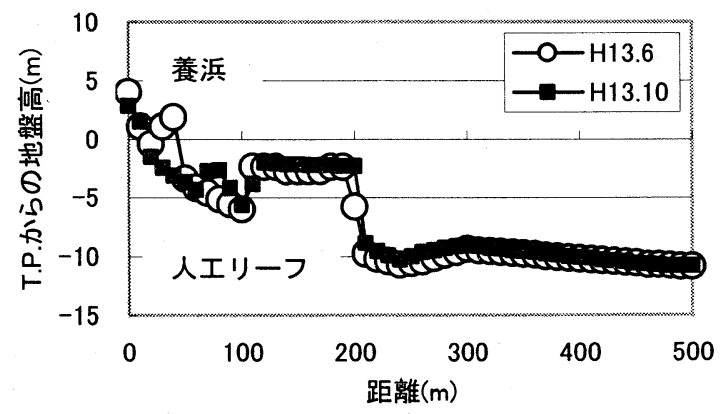

図一 6 養浜区間における海浜断面の変化（No.-3） 


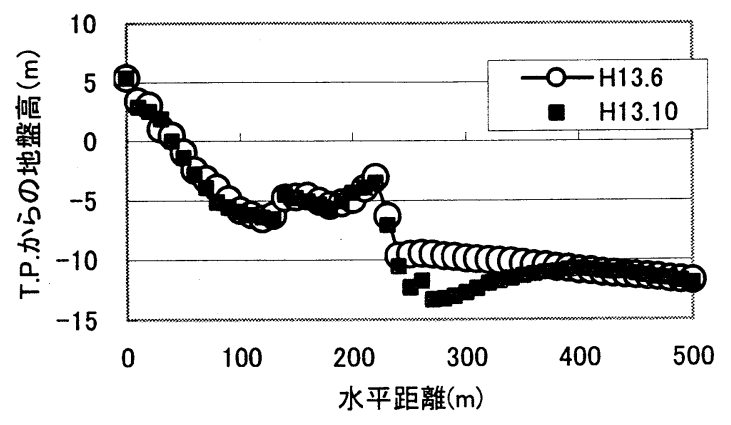

図-7 養浜下手側の海浜断面の変化（No.10）

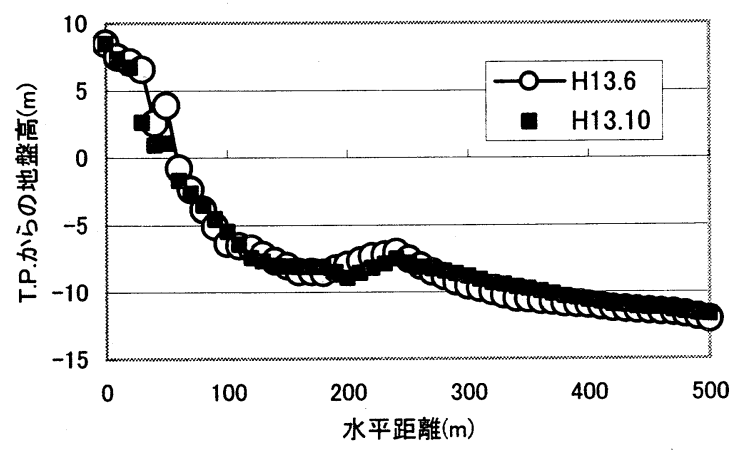

図－8 人エリーフ非設置部の海浜断面の変化（No.15）

浜断面が若干崩壊している様子がうかがえる。また， 人エリーフの背後には侵食された前浜の養浜砂が一 時的に堆砂したと考えられる状況が確認できる.

図一7は，養浜が実施されていない沿岸漂砂下手 側のNo.10における海浜断面を比較したものである. 人エリーフの設置区間であるが，リーフの天端が若 干歪な形状となっている。 さらに，リーフ前面では 大型台風の来襲によって $3 \mathrm{~m}$ 以上の局所洗掘が生じて おり，高波浪時における部分重複波と戻り流れなど の発生が関与しているものと考えられる.

人エリーフ (5号) が設置予定のNo.15における海 浜断面を比較したものが図－8である．同図から， 陸域で侵食が見られる。これは，人エリーフが完成 断面ではなく，波浪が直接消波ブロックに作用する 状態となっており, 台風期の高波浪によって消波ブ ロックは沈下し, 背後の保安林の護岸法面が崩壊す る状態と対応している。 また, 沖合 $200 \mathrm{~m}$ 付近に沿 岸砂州の形成が見られる。詳細に見ると, 砂州の岸 側が侵食され，沖側で堆積する様子がうかがえる.

図一９は，人エリーフ6号が設置され，背後にト ンボロ地形が形成されている地点である。同図から， 人工リーフ沖側では大きな差異は見られないが, 人 エリーフ背後で堆砂がさらに進展したことなど微地 形の変化が見られる。この人エリーフ6号の漂砂下 手側境界（No.20）の海浜断面を示せば図－100よ うである。同図から, 小さな沿岸砂州の存在や後浜 におけるバーム地形の形成などがうかがえる。また， このバーム地形は8月の簡易測量によると, No.20よ り下手側 $400 \mathrm{~m}$ 以上にわたって形成されていること が確認されており，2次元的な様相を呈している. したがって，人エリーフ6号より下手側では，沿岸

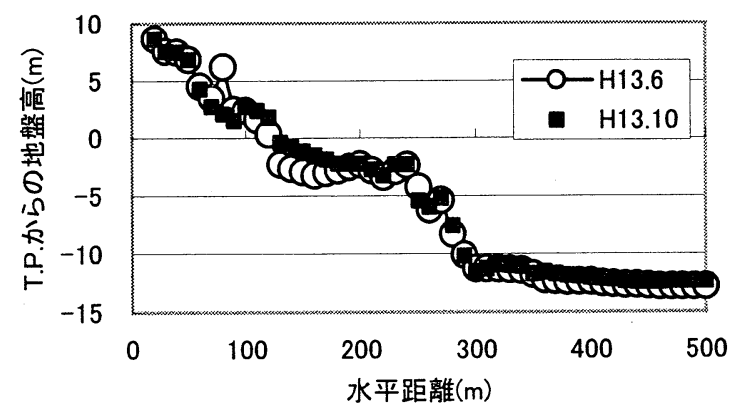

図－9人エリーフ6号の海浜断面の変化（No.18）

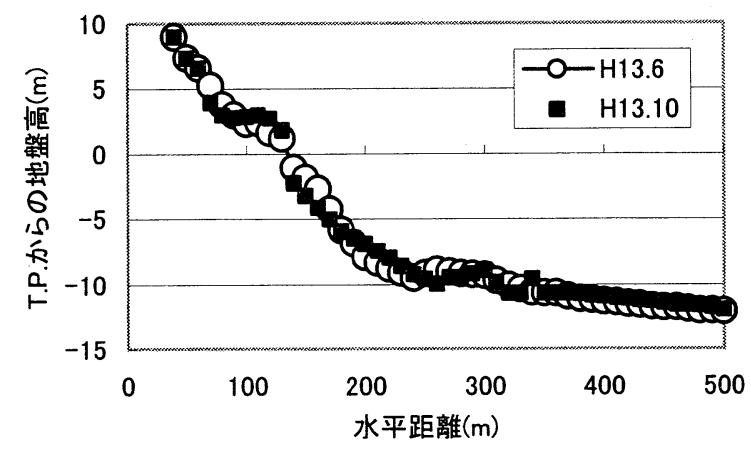

図-10 対象領域境界の海浜断面の変化（No.20）

方向に運ばれてきた砂砶の一部が岸向き漂砂によっ て大量に打ち上げられた可能性を示唆している.

(2) 人エリーフ6号背後の後浜地形

大型台風の来襲によって, 海浜断面が大きく変化 していることが明らかにされた，以下では，人工 リーフ6号周辺の後浜地形の特性について述べる.

図－11は，台風11号および15号来襲後の写真であ る. 人エリーフ6号の背後の護岸先端から, 漂砂下 手側に相当する熊野市を望む後浜地形の状況である. 流木やゴミが, 高波浪時の遡上域先端部に集積して いることがわかる. 一方, 台風15号来襲後, 流木な どは後浜から一掃されてなくなり, さらに，保全林 前面に堆積していた土砂を掃流して，人エリーフ背 後へと移動させた。

図ー12は人エリーフ6号背後の汀線付近より陸側 の後浜地形をより詳細に測量した測点を示したもの である. 図中には，人エリーフ6号（長さ $200 \mathrm{~m} \times$ 幅

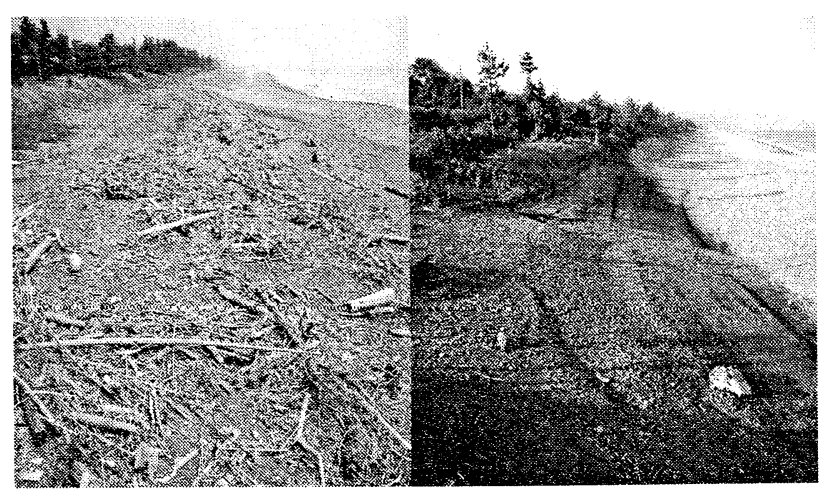

（a）台風11号通過後（8/29）（b）台風15号通過後（9/29） 図-11 台風来襲後の後浜の状況 


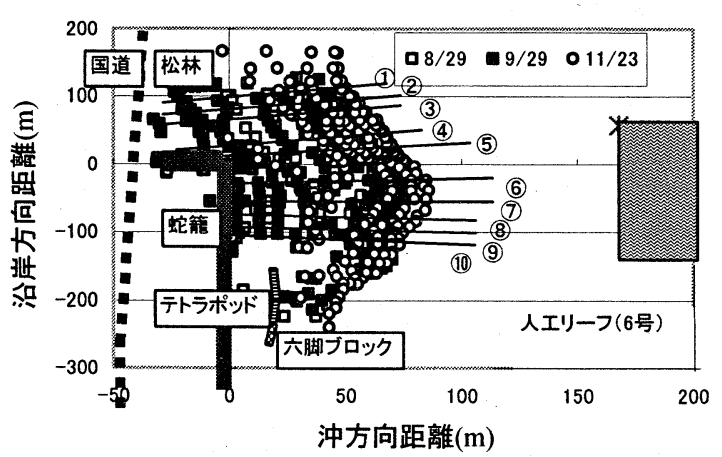

図-12 人エリーフ6号背後の後浜地形測点

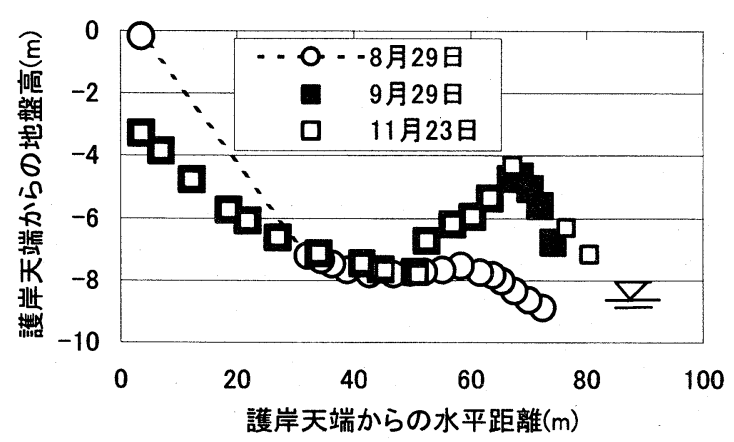

图ー13 後浜におけるバーム地形の形成（測線(6)

80m）を含めた周辺構造物の位置関係が併記されて おり，x方向を引き伸ばして表示している．同図か ら, 人工リーフ背後では汀線の形状がトンボロ地形 となっていることがよくわかる.

さらに，このトンボロ地形のほぼ中央に位置する 測線(6)断面において, 3回の地形測量結果を重㱛て 表示したものが，図ー13である．同図は護岸天端を 原点とし, 汀線際よりも陸側の後浜地形を測量範囲 としたものである。同図から，台風 11 号来襲後には 護岸天端から $8 \mathrm{~m}$ 程度下の汀線付近にバーム地形が 形成されていたが，台風 15 号接近後には，3m近く バーム地形が嵩上げされた。その 2 ケ後，バーム 地形の天端から岸側に大きな変動はないが，海側で は波浪や潮位の作用によってバーム前面が崩壊し，

汀線が前進していく様子がうかがえる.

この嵩上げされた土砂は供給されたのだろうか. 台風15号通過後には, 保安林の前面（図一12の(1)測 線）が侵食され約 $2 \mathrm{~m}$ の崖を形成した。その作用に よって松林が自立できず一部が倒壊するなどの被害 が出ている，また，国道沿いには，流木やゴミなど が集積しており，高波浪時の遡上波によって台風11 号で散乱した流木類を，保安林まで押し上げたもの と考えられる。図一12からもわかるように，人工 リーフ6号の背後の下側は, 蛇篭で保安林が保護さ れており，前面には異型ブロックによる消波堤が設 置されており遡上波による被害を受けにくい。した がって, 上側から入射した遡上波は保安林前面の土 砂を侵食しながら，トンボロ地形の中央部の凹地一 と土砂を輸送することになる。事実, 土砂の粒径が 異なるフロントが, 倒壊した松林からトンボロ地形 中央部へと形成されており，遡上波による後浜の土
砂輸送の激しさを示唆している.

\section{5. 沿岸漂砂量の推定}

七里御浜海岸は砂礫浜であり土砂の粒径が大きい ので底質の移動限界水深は小さく，人エリーフより 沖側一土砂が多量に流出することは考えにくい，そ こで，4 (1) で得られた深浅測量結果（平成13年6月 と11月）から，人エリーフ背後の前浜から後浜に至 る範囲を設定して, 各断面の土砂変動量を算定し, 台風期における沿岸漂砂量を見積ることにする.

図ー14は深浅測量が行なわれた区間において，同 一断面内の土量変化を表したものである.ただし， 岸沖方向の範囲については次のように取り扱った. 人エリーフの設置された箇所では, T.P.6mから人工 リーフ岸側の法尻まで, 人エリーフ未設置場所では, 人エリーフ沖側の法尻の水深に相当するT.P. $-7 \mathrm{~m} ま$ でとした. また, 図中の黒塗りは人工リーフが設置 されていない場所のデータであることを示している. 同図から，養浜区間の土砂はほとんどが流出し，部 分的に人エリーフの背後で堆砂されるが，養浜区間 で侵食される場所も少なくない。ささらに，人エリー フが設置されていないNo.15〜16では侵食傾向にあ り，その土砂は隣の人エリーフ6号背後にトラップ されていることなどがうかがえる.

さらに,この結果をもとにして, 累積の土砂変動 量（侵食：十）を示したものが図一15である. 同図 から，養浜を行なった区間（No.-5〜No.5）の土砂 変動量は20,650 $\mathrm{m}^{3}$, 養浜を実施してない区間（No.6

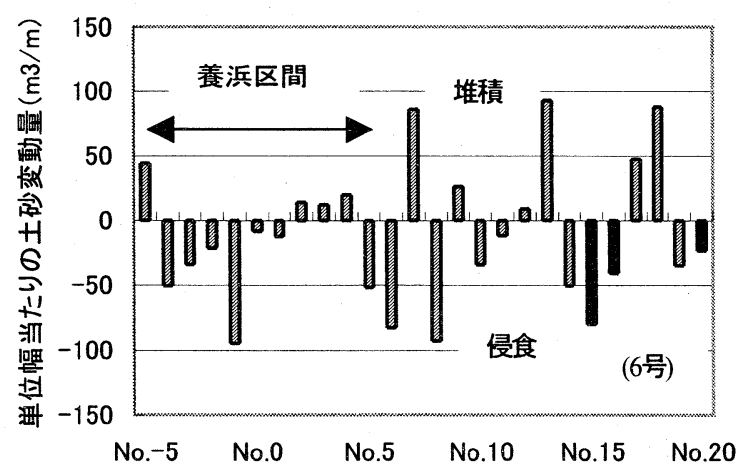

図-14＼cjkstart深浅測量による台風期の土砂变動量

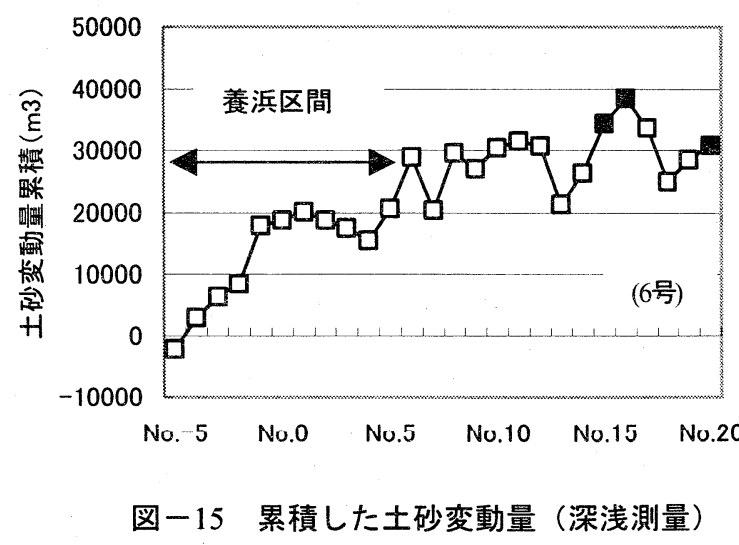


〜 No.20) では $10,200 \mathrm{~m}^{3}$ ，対象区間全体では $30,850 \mathrm{~m}^{3}$ となることがわかる. また，投入した養浜 砂の全体積は $36,460 \mathrm{~m}^{3}$ であり，梶ヶ鼻より上手側か らの土砂供給量はそれほど多くないので，台風期

（6月～11月）では養浜区間で約半分以上の土砂が 失われたことに相当する. その後, 養浜を実施して いない区間でも約 1 万 $\mathrm{m}^{3}$ の流出となり，特に人工 リーフ5号が設置されていないNo.15〜16区間では, 1 万 $\mathrm{m}^{3}$ 以上の土砂流出となっている. 人エリーフ 6 号によって一部は人エリーフ背後に堆砂されるもの の，その下手側（No.19～20）ではさらに5,000m減 少する。したがって，平成13年6〜11月（台風期） の対象区間の漂砂下手側境界における沿岸漂砂量は, 約 3 万 $\mathrm{m}^{3}$ と見積ることができる.

\section{6.おわりに}

以上, 三重県七里御浜の南端に位置する井田海岸 を対象に, DGPSによる汀線測量や地形測量を年数 回行い, 三重県が行なった養浜のモニタリング調査 のデータ解析を通して，台風期における汀線や海浜 地形の変動特性を波浪特性と関連づけて考察した. 昨年に相次いで来襲した台風11号，15号によって保 安林や護岸法面の一部が崩壊し, 遡上波の作用に よって後浜の地形だけでなく，人エリーフ周辺の海 浜地形が大きく変動したことが明らかにされた。さ らに, 人エリーフ6号の背後では, 高さ約 $3 \mathrm{~m}$ のバー 厶地形が形成され, その後の汀線を前進させるなど トンボロ地形を進展させた。また，養浜工の深浅測 量結果から沿岸漂砂量の境界条件を明らかにし, 台 風期の沿岸漂砂量は, 約 3 万 $\mathrm{m}^{3}$ と見積られた。 今後, 漂砂量公式についても検討を加えながら, 海浜変形 モデルによる解析を進める予定である.

最後に, 本研究は土木学会中部支部平成13年度研 究調查委員会の研究助成「水系一環の土砂マネジメ ントを理念とする熊野川・七里御浜海岸の土砂移動 の実態とその予測・対策に関する調查研究委員会 RG : リサーチグループ代表 和田 清」の一環とし て行われたことを付記する.
謝辞：本研究の遂行に際して, 現地調査資料につい ては，三重県県土整備部のご協力を賜った。さらに, 「里御浜海岸侵食対策検討会 (座長 : 名古屋大学 大学院工学研究科 岩田好一朗教授）」の適切なご 助言を頂いた。また, 現地調査や結果の整理は, 岐 阜工業高等専門学校卒業生高島明君（現岐阜県庁） の多大な協力に負うところが大きい. 末尾ながら, ここに記して謝意を表する.

\section{参考文献}

1)宇多高明 : 日本の海岸侵食, 山海堂, pp.265-275, 1997.

2)本間 仁監修・堀川清司編: 海岸環境工学, 海岸過程 の理論・観測・予測方法, 東京大学出版会, 582p., 1985.

3)宇多高明・後藤康長・山本幸次: 三重県七里御浜海岸 の海浜変形機構に関する一考察, 海岸工学論文集, 第 39巻, pp.351-355, 1992.

4)山本幸次・佐藤慎司・野口賢二・宮野正実 : 熊野川を 土砂供給源とする海岸の海浜変形と砂磁層厚, 海岸工 学論文集, 第46巻, pp.351-355, 1999.

5)三重県熊野土木事務所 : 七里御浜海岸設計業務委託報 告書, 94p., 1991.

6)三重県熊野土木事務所 : 平成9年度井田地区海岸国補海 岸高潮対策工事（汀線および底質地層の調查解析）報 告書, 89p., 1998.

7)和田 清 - 中澤真紀 - 水谷法美 - 鷲見浩一: 熊野灘七 里御浜におけるマクロ的な海浜変形と海岸侵食の実態, 土木学会中部支部研究発表会講演概要集, PS-2, pp.3$4,2000$.

8)和田 清 - 水谷法美・村上宗隆 : 七里御浜海岸の瓶殿 港周辺における海浜変形の素過程, 海洋開発論文集, 第16巻, pp.291-296, 2000.

9)和田 清 - 森岡睦門 - 伊藤育雄 : 七里御浜海岸におけ る汀線および後浜の地形変動と波浪特性, 土木学会中 部支部研究発表会講演概要集, pp.5-6, 2001.

10)和田 清・水谷法美: 三重県井田海岸における季節的 な海浜変形特性に関する一考察, 海洋開発論文集, 第 17巻, pp.535-540, 2001.

11)三重県: 第8回七里御浜海岸侵食対策検討会資料, $57 \mathrm{p}$., 2002. 